\title{
REDES DE INTEGRAÇÃO CONCEPTUAL EM NARRATIVAS SOCIOLINGUÍSTICAS
}

\author{
Jan Edson Rodrigues LEITE* \\ Mábia Nunes TOSCANO** \\ Andréa de Oliveira Gomes MARTINS ${ }^{* * *}$
}

- RESUMO: Este artigo pretende descrever a emergência de Redes de Integração Conceptual em dados da fala de usuários da variedade sociodialetal pessoense, a fim de mapear o uso de estratégias cognitivas de conceptualização na construção de narrativas orais. Para isso, utilizamos o corpus do Projeto Variação Linguística do Estado da Paraíba (VALPB) que se propõe, a partir dos dados coletados, apresentar o perfil linguístico do falante da Paraíba. A partir desse corpus, fizemos a classificação e a análise das ocorrências de redes de integração identificadas; observamos e descrevemos as relações vitais estabelecidas durante a integração conceitual; e procuramos descrever o funcionamento da tipologia de redes a partir da mesclagem conceitual resultante das conceptualizações presentes nas narrativas orais produzidas pelos indivíduos nos contextos de uso da língua. Orientamo-nos sob a perspectiva da Linguística Cognitiva, especialmente dos trabalhos de Fauconnier e Turner (2002). Por fim, organizamos os resultados da análise, discutindo diversas ocorrências nas diferentes variáveis encontradas no corpus.

- PALAVRAS-CHAVE: Mesclagem. Redes de integração conceitual. Rede especular. Rede simples. Rede de duplo alcance. Rede de alcance único. Conceptualização.

\section{Introdução}

Este artigo descreve achados de uma pesquisa cujo fim mais amplo é o de investigar o envolvimento de nosso sistema conceptual - nossas motivações cognitivas - no processo de escolha dos itens lexicais dentre as variantes sociodialetais disponíveis para o falante, a partir da categorização que este faz da realidade sociocultural. O escopo da pesquisa aqui apresentada é o mapeamento dos usos de certas operações cognitivas complexas (como a criação de redes de integração conceitual, mesclagem, atividades de compressão de relações conceituais vitais) por falantes da variedade linguística pessoense agrupados, no corpus analisado, sob variáveis de idade, sexo e escolaridade. No decorrer deste artigo, pretendemos responder às seguintes questões: 1) Como a Integração Conceptual se organiza em redes, e não em processos pontuais, considerando a

\footnotetext{
* UFPB - Universidade Federal da Paraíba. João Pessoa - PB - Brasil. 58051-900 - jan.edson@pq.cnpq.br

** UFPB - Universidade Federal da Paraíba. João Pessoa - PB - Brasil. 58051-900 - mabia_toscano@hotmail.com

*** UFPB - Universidade Federal da Paraíba. João Pessoa - PB - Brasil. 58051-900 - andr3aogm@hotmail.com
} 
existência de uma tipologia para esse fenômeno (redes simples, redes de alcance único, de alcance duplo, complexa, etc.) identificável na atividade linguística descrita, e 2) Como as relações conceptuais vitais (causa-efeito; função-valor; identidade; analogia) são comprimidas em Redes de Integração Conceptual que permeiam a atividade narrativa. Assim, nosso interesse é descrever o funcionamento de processos cognitivos que subjazem ao uso da linguagem. Portanto, a escolha de uma variedade linguística específica não nos leva a predizer que haverá diferença nesse funcionamento, mas nos ajudará a mapear como a variedade em uso esquematiza domínios cognitivos presentes em nosso sistema conceitual.

\section{Marco teórico}

As contribuições trazidas pela Linguística Cognitiva nos últimos 30 anos têm atribuído novo vigor à reflexão sobre os processos mentais subjacentes ao uso das línguas naturais. Essa abordagem da Linguística, por meio de seus construtos teóricos e de seus métodos, permite mapear com relativa clareza e precisão a complexidade dos processos cognitivos envolvidos na comunicação verbal, especialmente quanto aos aspectos significativos da linguagem em uso, ao mesmo tempo em que confere às expressões linguísticas, que correspondem à parte aparente desse processo, uma natureza conceptualista, dinâmica, perspectivada e experiencial.

A abordagem cognitiva aqui esposada adota a ideia de corporeidade segundo a qual, o corpo está intimamente ligado à mente. A atuação linguística do homem é fundamentada em esquemas anteriores ou co-ocorrentes à atividade linguística. Na estruturação desses esquemas, a experiência corpórea tem papel crucial.

Nessa perspectiva, o tratamento cognitivo da linguagem se distingue da visão formal tradicional já que não deduz o significado linguístico como resultante de operações lógicas, desencarnadas das experiências de uso pelos falantes, mas o considera como uma atividade de construção cognitiva - não individualizada em uma mente igualmente desencarnada, mas como subproduto de capacidades sensório-motrizes, postas em uso nas práticas, nas instituições e nos artefatos socioculturais, aos quais a espécie humana se encontra vinculada, em consequência de sua própria evolução. Essa mudança de foco permitiu a observação da relação entre os aspectos gramaticais de uma língua, os sistemas cognitivos que cooperam no processamento e na compreensão das formas linguísticas e as práticas socioculturais segundo as quais uma língua natural é posta em um uso.

Os estudos de Linguística feitos sob essa orientação contribuem não apenas para a compreensão do conhecimento linguístico, mas para o estabelecimento, 
nas ciências cognitivas, de um campo de estudos que não separa conhecimento linguístico de outros sistemas cognitivos - como se aquele fosse autônomo e, por isso, produz explicações satisfatórias para o entendimento de como os sistemas cognitivos (perceptuais, linguísticos, motores, espaciais, mnemônicos, etc.) agem integradamente na apreensão/compreensão do indivíduo sobre sua realidade. Entre esses estudos, queremos enfatizar neste trabalho o modelo teórico de compreensão denominado Teoria dos Espaços Mentais (FAUCONNIER, 1994, 1997), e seus desdobramentos analíticos a partir da postulação da Teoria da Mesclagem ou Integração Conceitual (FAUCONNIER; TURNER, 2002).

De acordo com Ferrari (1999, p.116), a Teoria dos Espaços Mentais, oferece "[...] um modelo geral para o estudo da interação entre conexões cognitivas e línguas naturais, apontando a provável universalidade do fenômeno de conexão entre domínios conceptuais no pensamento e na linguagem." O eixo dessa teoria é que quando as pessoas atuam em situações de interação linguística são estabelecidos diferentes espaços mentais os quais são "[...] construídos, estruturados e ligados, a partir de sua gramática, do contexto e da cultura, e são motivados pela sua intenção comunicativa." (RODRIGUES, 2008, p.111). Essas estruturas se estabelecem para fins de compreensão e de ação locais.

Existem expressões linguísticas capazes de acionar domínios cognitivos envolvidos na atividade de conceptualização: são os chamados construtores de espaços mentais (spaces builders). Essas estruturas linguísticas evocam vários tipos de espaços mentais como, por exemplo: a) Crença: "Acho que as aulas começam amanhã"; b) Imagem: "Na foto você parece alegre"; c) Hipótese ou contrafactualidade: "Se eu fosse você arrumaria logo as malas"; d) Escala: "Dom Quixote é um tipo de herói"; e) Tempo: "Ontem à noite saímos para jantar"; f) Drama: "Na peça, Edson Celulari é Dom Quixote"; g) Lugar: "Na Paraíba, existem belas praias para visitar"; h) Modelo cultural: "Na nossa religião, o divórcio não é aprovado", etc. Os espaços mentais são entendidos como um fenômeno cognitivo de natureza universal, mas as construções linguísticas que os ativam no discurso são locais, mobilizadas no momento da interação comunicativa e, de certa forma, articulados com a cultura e a situação contextual nas quais a língua e os demais recursos cognitivos são postos em uso.

Dois elementos são essenciais a esse modelo teórico: as noções de domínios e de projeções. No desenrolar do discurso, surgem diversas construções cognitivas, oriundas de estruturas conceituais que organizam as informações da nossa memória, de modo que acessamos não apenas os itens linguísticos que ativam os repertórios disponíveis, mas também as categorias conceituais, os modelos culturais e os modelos cognitivos idealizados que emolduram nosso pensar e nosso falar. Entre essas estruturas estão domínios cognitivos de natureza estável ou dinâmica (local). Os domínios locais correspondem aos espaços mentais já 
mencionados acima. Os domínios estáveis correspondem a "estruturas de memória pessoal" (MIRANDA, 1999), como frames e modelos cognitivos idealizados. Eles organizam internamente os domínios locais (ou espaços mentais).

As projeções constroem e ligam domínios. Quando pensamos sobre determinados domínios, muitas vezes, usamos estruturas de outros domínios e seu vocabulário correspondente. É o caso de certos tipos de metáforas em que não há possibilidade de se estruturar o conhecimento sobre um domínio, digamos TEMPO, sem utilizar sistemática e consistentemente a estrutura linguístico-conceitual de outro domínio, digamos ESPAÇO.

Essas projeções nos auxiliam no entendimento das intenções dos falantes e são evidências de que processos conceptuais (metafóricos, metonímicos, categoriais, imagem-esquemáticos, etc.) fazem parte da linguagem cotidiana (RODRIGUES, 2008). As projeções conceptuais estão presentes nas relações entre os espaços mentais que são domínios dinâmicos e temporários produzidos pelos falantes durante o discurso.

Essa teoria sugere a existência de quatro espaços mentais relacionados durante a projeção entre domínios que se organizam da seguinte maneira:

\section{Figura 1 - Diagrama de quatro espaços}

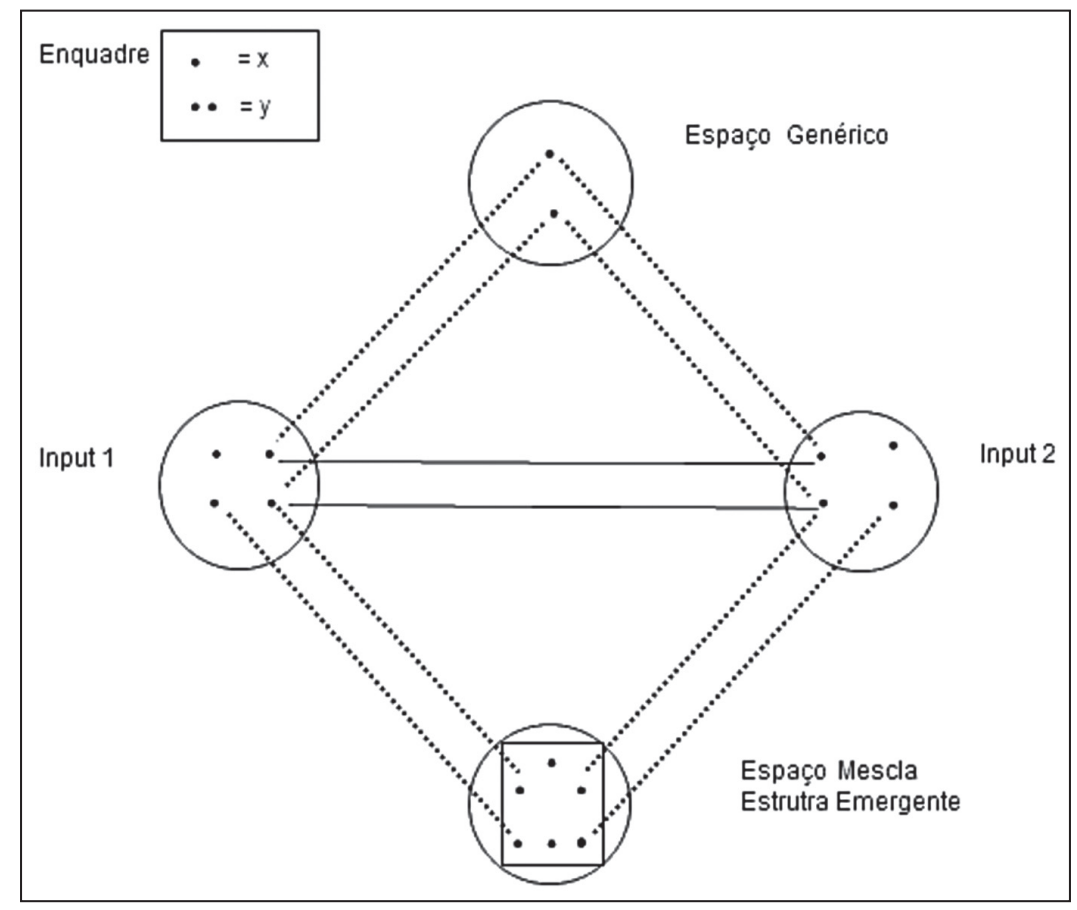

Fonte: Elaboração própria. 
Tem-se, então, um espaço genérico que se constitui de uma estrutura conceitual mais geral compartilhada pelos dois espaços influentes (ou inputs), e também um espaço-mescla no qual há a combinação seletiva das representações dos espaços influentes. Esse espaço-mescla não corresponde a uma soma dos espaços anteriores, mas estabelece uma nova conceptualização, seja no terreno da linguagem e do discurso, seja no terreno das artes, da inovação tecnológica, da religião, seja no terreno da matemática.

A integração conceptual de domínios cognitivos diferentes, descrita com exaustão na Teoria da Mesclagem, nos dá acesso a uma das mais interessantes capacidades humanas: a imaginação, um subproduto da identificação entre conceitos de diferentes domínios na criação de estruturas conceituais novas. A mesclagem possibilitou aos seres humanos desenvolverem a arte, a ciência, a cultura, ferramentas e etc. (FAUCONNIER; TURNER, 2002). Apesar de este não ser um processo do qual temos consciência, ele está presente na maioria das operações cognitivas que dizem respeito à estruturação do conhecimento humano.

A mesclagem é um processo cognitivo que envolve dois espaços de input (Input 1 e 2) e opera sobre um terceiro espaço - o domínio-mescla. O espaço mesclado herda partes dos dois espaços influentes, porém possui uma configuração própria, como representado acima na figura 1. Ainda na visão do autor, essa operação, apesar de ser simples, pode explicar vários fenômenos linguísticos e nos permite conhecer as relações entre os processos cognitivos e as estruturas linguísticas.

Chiavegatto (1999), observando os processos cognitivos de mesclagem de vozes, explica que existem condições que devem ser satisfeitas para que se identifique um processo de mesclagem:

- Mapeamentos dos espaços intercruzados, em que temos mapeamentos parciais de contrapartes de dois espaços influentes;

- A existência de um espaço genérico que reflete estruturas geralmente mais abstratas comuns aos dois espaços influentes;

- Os espaços influentes 1 e 2 que são projetados parcialmente sobre o espaço-mescla;

- O espaço-mescla possui uma estrutura emergente própria distinta das estruturas dos espaços influentes de três modos relacionados que são:

- Composição: as projeções dos inputs constituem no espaço-mescla novas relações utilizáveis que não existiam nos espaços influentes separadamente;

- Completamento: "[...] o padrão da fonte mesclada, estruturado pela herança das estruturas inputs é 'completado' na estrutura emergente mais ampla." (CHIAVEGATTO, 1999, p.104).

- Elaboração: com a mescla completada, a estrutura pode ser elaborada por um processo cognitivo que ocorre em seu interior segundo sua própria lógica emergente. 
Dependendo do tipo de projeção que se forma resultando na mescla, originam-se diferentes tipos de redes de integração conceitual. As redes podem ser simples, especular, de alcance único e de alcance duplo.

As redes simples apresentam um espaço influente com funções sem valores e outro espaço com elementos sem enquadre. Na mescla, há uma fusão dos elementos livres de um espaço com as funções do outro. Turner (2008) exemplifica esse processo da seguinte maneira: se queremos dizer que duas pessoas, por exemplo, João e Tiago possuem uma relação de parentesco, podemos dizer simplesmente "João é o pai de Tiago". Em um dos espaços (1), vamos ter o enquadre familiar que é elaborado para aceitar certos tipos de valores, como a relação de parentesco - pai e filho. No outro espaço (2), temos apenas João e Tiago, valores que se identificam com as funções representadas em (1). No espaço-mescla, João é o pai de Tiago, já que existe um novo papel projetado seletivamente para a mescla que é "pai de Tiago".

Nas redes especulares, temos dois espaços influentes que compartilham do mesmo enquadre o qual é projetado para o espaço genérico e herdado pelo espaço-mescla. Um exemplo desse tipo de rede é apresentado por Rodrigues (2010, p.86): "Em 1984, João do Pulo bateu seu próprio recorde de 1980 no salto triplo olímpico." Temos dois "João do Pulo", um em 1980 e outro em 1984, que executam - cada um em um domínio temporal diferente - um salto triplo constituindo assim os dois espaços influentes. No espaço-mescla, emerge uma estrutura em que João do Pulo 1984 supera o recorde obtido por João do Pulo 1980, ou seja, no domínio temporal localizado no espaço-mescla, João do Pulo vence a si mesmo.

As redes de alcance único possuem dois espaços influentes cada um com um enquadre organizacional próprio. Rodrigues (2010, p.87) ilustra esse tipo de rede com o seguinte exemplo: "Empresários de TV boxeiam entre si para ganhar audiência". Temos aqui um espaço influente com dois boxeadores em um enquadre de luta de boxe, no qual um é o vencedor. No outro espaço, temos os empresários que competem entre si. Trata-se de um enquadre de competição de estratégias e não de golpes físicos. No espaço-mescla se projeta apenas o enquadre da competição profissional. Esse tipo de rede é altamente produtivo quanto à estruturação de um domínio cognitivo em termos de outro, característica da metáfora conceitual.

As redes de alcance duplo possuem enquadres organizacionais diferentes para cada espaço influente, além de um para o espaço-mescla, que inclui partes de cada um dos enquadre e uma estrutura emergente nova. Esse tipo de rede envolve a mesclagem de enquadres. O exemplo clássico para a mesclagem de enquadres "Vanity is the quicksand of reason" (A vaidade é a areia movediça da razão) apresenta um espaço, cujo enquadre correlaciona a areia movediça 
aos obstáculos encontrados por um viajante em seu caminho rumo a certo destino; o outro espaço corresponde à razão e está estruturado por elementos característicos da busca intelectual pelo aumento da razão. Os dois espaços se projetam, já que a busca pela razão se identifica com o destino do viajante. Nesse caminho, ao avançarmos rumo à razão, corremos o risco de sucumbir à vaidade. Cair na areia movediça não é, entretanto, o resultado natural de qualquer viagem. O enquadre para a mescla, nesse exemplo, requer uma relação causal entre a vaidade e a diminuição da razão, o que não se verifica nos enquadres dos outros espaços.

Outro exemplo desse tipo de rede é a interface computacional que denominamos de desktop. Em um espaço mental, temos um enquadre relacionado a elementos de um escritório físico que contém pastas, arquivos, fichários, lixeiras. O outro espaço está organizado pelo enquadre dos comandos tradicionais de um computador e contém elementos como encontrar, substituir, salvar, copiar. No espaço-mescla, temos um enquadre diferente com elementos que tornam compatíveis as linhas de comando de um software com a manipulação de objetos reais de um escritório através de aplicativos digitais que possibilitam "salvar arquivos" e "criar pastas", "jogar arquivos na lixeira" mesclando, dessa maneira, o ambiente físico de escritório com o virtual.

Os processos de mesclagem, responsáveis pela integração que fazemos entre domínios cognitivos diferentes com a finalidade de elaborar descrições conceituais inovadoras, são percebidos tanto em ocorrências de construções linguísticas, como é o caso dos exemplos trazidos para as redes simples, especulares e de escopo único, quanto em estruturas menos específicas como o exemplo do desktop apresentado acima. O processo de mesclagem, além disso, contribui para a compreensão do pano de fundo conceitual de certas estruturas gramaticais, como os verbos atirar e morrer nos exemplos: (1) Joaquim atirou a roupa suja no cesto e (2) Eu morri o carro na subida da ladeira.

Em (1), a mesclagem convencional representada na estrutura sintática SN V SN Sprep é projetada a partir da ação de Joaquim sobre a roupa, indicada pelo verbo atirar em um dos espaços (Input 1: ação do sujeito sobre o objeto) e pelo movimento da roupa em direção ao cesto (Input 2: movimento causado do objeto), os quais são integrados por uma relação de causa e efeito (Mescla: efeito da ação do sujeito na localização do objeto).

No exemplo (2), a construção mesclada $\mathrm{SN}_{1} \mathrm{~V}_{2} \mathrm{SN}_{2}$ Sprep (Eu morri o carro na subida da ladeira) ocorre a partir da projeção da estrutura contida em um espaço de input $\mathrm{SN}_{1} \mathrm{~V}_{1} \mathrm{SN}_{2}$ (Eu dirigi o carro) e da estrutura presente em outro espaço $\mathrm{SN}_{2}$ $\mathrm{V}_{2}$ Sprep (O carro morreu na subida da ladeira). Como cada um desses espaços se estrutura a partir de um enquadre diferente, temos uma rede de alcance duplo que explica a inovação conceitual responsável pelo sentido inédito do verbo morrer. 


\section{Figura 2 - Mesclagem Sintática}

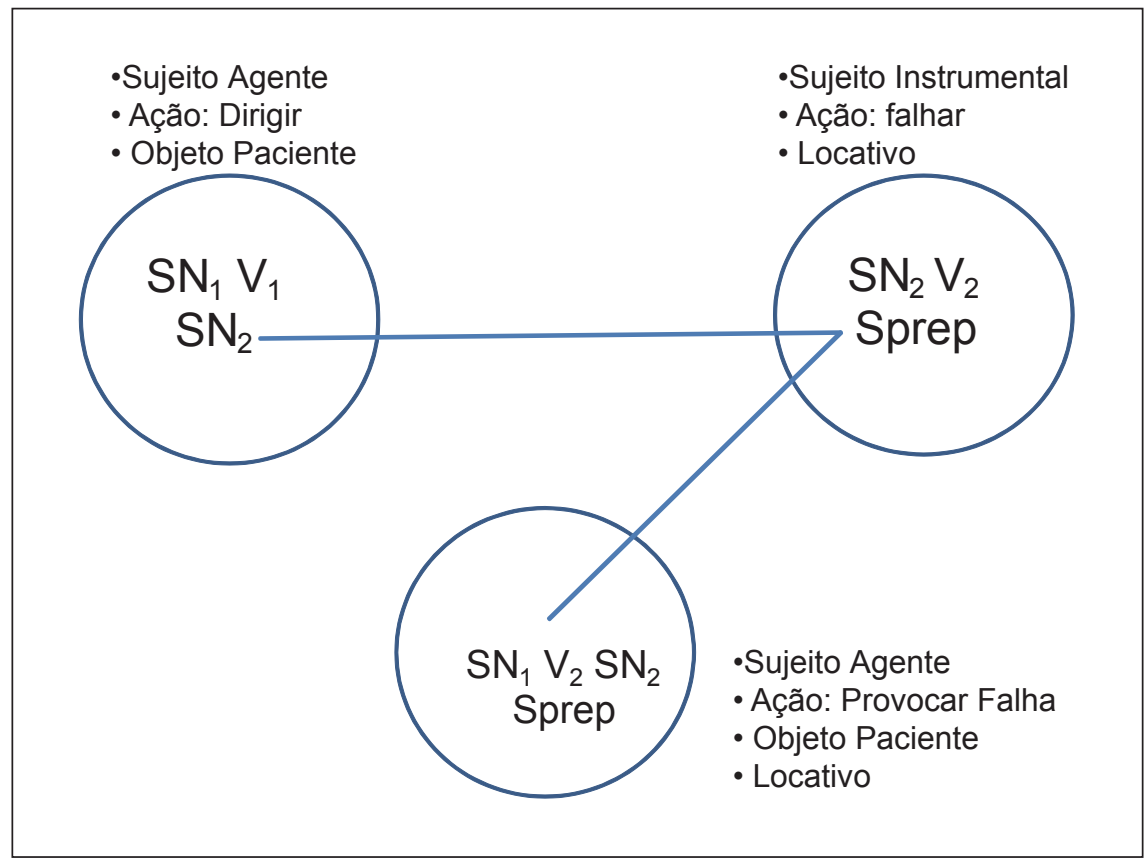

Fonte: Elaboração própria.

As redes de integração conceitual não são classificações estanques. Na verdade, elas formam um contínuo de espaços mentais usados na organização do nosso conhecimento e mobilizados de maneira dinâmica para dar conta da imaginação e criatividade.

\section{Metodologia}

Utilizamos como corpus de análise os dados armazenados sobre o falar pessoense, constantes do Projeto Variação Linguística no Estado da Paraíba VALPB (HORA; PEDROSA, 2001). O VALPB pretendeu desenvolver, a partir do corpus coletado, o perfil linguístico do falante da Paraíba, em seus aspectos fonológicos e gramaticais. Esse banco de dados contém uma amostragem do português falado na Paraíba, colhida através de entrevista com 60 informantes, dentro da metodologia variacionista da sociolinguística.

Surgido em 1993, noVALPB encontram-se armazenados dados de fala em fitas de áudio estratificados conforme as variáveis: 1) Sexo (30 informantes do sexo masculino e 30 informantes do sexo feminino); 2) Faixa etária (20 informantes de 
15 a 25 anos, 20 informantes de 26 a 49 anos e 20 informantes com mais de 50 anos); e 3) Anos de escolarização (12 informantes: nenhum; 12 informantes: 1 a 4 anos; 12 informantes: 5 a 8 anos; 12 informantes: 9 a 11 anos; 12 informantes: mais de 11 anos). ${ }^{1}$

A vantagem da utilização desse corpus para a análise do fenômeno da mesclagem e das redes de integração conceitual é que, em geral, os dados utilizados na teoria são tomados de outras línguas, especialmente do Inglês, ou são analisados textos elaborados para finalidades específicas diferentes da conversação ou da fala espontânea, como é o caso dos textos de humor, textos jornalísticos, publicidade, etc. que demandam uma elaboração refinada dos processos cognitivos para atender aos efeitos semântico-discursivos desses textos. Nesse caso, preferimos analisar exemplos de discursos localmente situados em uma variedade linguística não padrão proveniente da fala de indivíduos com alta e baixa escolarização, já que esse tipo de corpus não é comum nos trabalhos que lidam com o fenômeno em questão. Essa escolha é suportada pelos seguintes pressupostos:

Se o fenômeno da integração conceitual em redes é uma operação cognitiva universal, então (1) não haverá diferenças entre como falantes de uma variedade linguística $X$ executam essa operação na comparação com falantes de uma variedade linguística Y; (2) não haverá diferenças na execução dessa operação entre falantes com maior ou menor escolaridade; (3) não haverá diferenças na execução dessa operação entre falantes de faixa etária maior ou menor.

Os dados desse corpus são transcritos segundo as normas que seguem: 1) Pausas e interrupções: +. 2) Dúvida quanto à palavra: a palavra sob dúvida está entre colchetes angulares $<>$. Ex.: Ele <andava $>$ muito. 3) Cruzamento de vozes: os enunciados pronunciados por dois falantes ao mesmo tempo são sublinhados. Ex.: Que legal! 4) Pontuação: 4.1 ponto de interrogação nas frase interrogativas e o de exclamação em frases exclamativas são mantidos. Ex.: Aí, eu falei: que bom! Então ele perguntou: - onde você estava? 4.2 os outros sinais de pontuação também são mantidos. 5) Alongamento de vogal: após a vogal alongadas são colocados dois pontos. Ex.: Ele gostava, e co:mo gostava! 6) Silabação: para indicar a silabação é colocado o hífen no meio da palavra. Ex.: ca-fé, ca-mi-nha-da etc. 7) Repetições: letras ou sílabas repetidas são transcritas. Ex.: Aí, e e ele foi pra casa de de Carlos. 8) Palavra incompleta: a palavra repetida está entre colchetes [ ]. Ex.: Ele comprou um [carr], uma bicicleta. 9) Comentários do transcritor: atitudes não linguísticas do informante estão entre parênteses. Ex.: Ele gosta de mim (risos). 10) Intrusão de outro informantes: o comentário está entre barras / /. Ex.: F1 Ah, eu acho isso muito bom, /ah, eu também acho/ mas meu pai não gosta. 11) Palavra ou trecho ininteligível: comentário está entre chaves \{\}. Ex.: Maria queria comprar \{inint\}, a mãe dela falou que não queria. Na transcrição dos dados, foram mantidos: a) Os apagamentos: no lugar do segmento apagado consta zero Ex.: 'mesmo' = meOmo, 'brincando' = brincanOo, 'rapaz' = rapayO etc

b) Ausência de marca de concordância: também foi colocado zero . Ex.: 'As casas bonitas'= As casaO bonitaO... c) Itens lexicais que fazem parte da fala coloquial são mantidos. Ex.: vixi, num, cum, ni, vissi etc. d) Segmentos epentéticos são colocados. Ex.: Luyz, fayz, avoar, cawso etc. Quando a inserção for de glide, aparece "y" ou "w". e) Casos de apagamento silábico são mantidos. Ex.: tava, ta etc. f) As monotongações são transcritas. Ex.: 'O rapaz roubou o ouro' = O rapaz robô o oro. O acento deve ser colocado para evitar ambiguidade com outra forma existente, caso "roubo". 
Se o fenômeno da integração conceitual em redes subjaz e modela o funcionamento da linguagem, em termos conceituais e estruturais, pode-se predizer, portanto, que o fenômeno se atualizará em variedades linguísticas orais espontâneas do mesmo modo como se atualiza em textos escritos elaborados em variedade padrão.

Assim, a hipótese dessa pesquisa é a de que o sistema conceitual dos falantes das variedades sociodialetais (assim com a pessoense) se organiza - através das operações cognitivas aqui descritas - com a mesma complexidade e obedecendo aos mesmos princípios de estruturação conceitual, independentemente das contingências socioculturais relativas a cada variedade de língua.

Como hipótese nula, tem-se que diferenças entre os sistemas culturais relativos ao uso de uma dada variedade ou língua natural seriam acompanhadas de diferenças no sistema conceitual dos falantes dessa variedade ou língua e, consequentemente, as operações cognitivas que modelam nosso pensar e falar estariam sujeitas a diferentes princípios e níveis de complexidade.

Mesmo não sendo esta pesquisa experimental, e sim descritiva, a rejeição da hipótese nula, por meio da verificação de que as operações de integração conceitual ocorrem segundo os mesmos princípios, independente das variáveis sociolinguísticas encontradas no corpus, das diferenças entre modalidade escrita e oral e das diferenças entre variantes da língua padrão e das variedades sociodialetais, é um bom critério para testar a falseabilidade da teoria, já que a relativização de seus princípios levaria à adoção de explicações ad-hoc para cada nuance da organização conceitual por trás das manifestações linguísticas heterogêneas, diversificadas e culturalmente situadas.

Ressaltamos, nesse sentido, que os resultados sobre o funcionamento das redes de integração conceitual não estão diretamente vinculados à variedade pessoense, já que, segundo nossa hipótese, qualquer variedade deveria apresentar a mesma organização conceitual como pano de fundo ao seu uso. As redes de integração são um mecanismo cognitivo universal para a conceptualização e têm uma manifestação linguística (entre outras) especificada para cada contexto comunicativo. Essa manifestação "específica" preserva as estruturas universais e os princípios fundamentais da mesclagem e das redes.

Em termos procedimentais, nossa análise se iniciou pela identificação das ocorrências da mesclagem conceptual. A partir da leitura do corpus, marcamos as ocorrências e depois as listamos em uma tabela que apresenta o seguinte formato: 
Tabela 1 - Ocorrências

\begin{tabular}{|l|l|l|l|l|l|}
\hline OCORRÊNCIA & TIPOLOGIA & INFORMANTE & LOCALIZAÇÃO & FRAGMENTO & OBSERVAÇÃO \\
\hline & & & & & \\
\hline
\end{tabular}

Fonte: Elaboração própria.

É importante ressaltar que a localização é dada pela numeração das linhas dos trechos identificados, essa numeração recomeça a cada informante. Por fim, contabilizamos as ocorrências.

Em seguida, retomamos a leitura do corpus observando apenas as redes detectadas e partimos para a classificação da tipologia das redes em simples, de alcance único, de alcance duplo e especulares. Após a classificação, iniciamos o processo de exame das ocorrências. Para empreender a análise, tomamos como modelo a proposta de Coulson e Oakley (2003) que sugerem que a análise de redes de integração conceitual siga os seguintes passos:

- Introdução de um exemplo que se supõe envolver a mescla;

- Descrição da estrutura geral em cada espaço da rede de integração, ou seja, descrever a estrutura dos inputse do espaço genérico e identificar os mapeamentos, os elementos e as relações entre os espaços;

- Depois se passa à descrição do espaço-mescla evidenciando os aspectos vindos de cada um dos inputs, nesse momento é relevante apresentar uma diferenciação entre a estrutura emergente e os inputs, essa diferenciação é como o pesquisador justifica que a mescla faz surgir uma nova conceptualização e não uma cópia ou soma dos espaços de input.

As redes foram classificadas segundo a tipologia estabelecida por Fauconnier e Turner (2002) em: simples, especular, de alcance único e de alcance duplo. À medida que executávamos essa etapa de classificação, observamos a existência de estruturas emergentes procedentes das projeções conceptuais que instituíam as redes. A partir daí, passamos à análise das ocorrências encontradas, durante a qual nosso objetivo foi observar como ocorrem os mapeamentos cognitivos realizados pelos falantes e expressos nas mesclagens conceituais que se realizam linguisticamente. Observamos, durante essa etapa do trabalho, as relações vitais estabelecidas durante a integração conceitual.

\section{Resultados e discussões}

Na contagem dos resultados, de acordo com a tipologia das redes, obtivemos os seguintes resultados demonstrados no gráfico e na tabela abaixo: 


\section{Gráfico 1 - Porcentagem das redes de integração identificadas no corpus.}

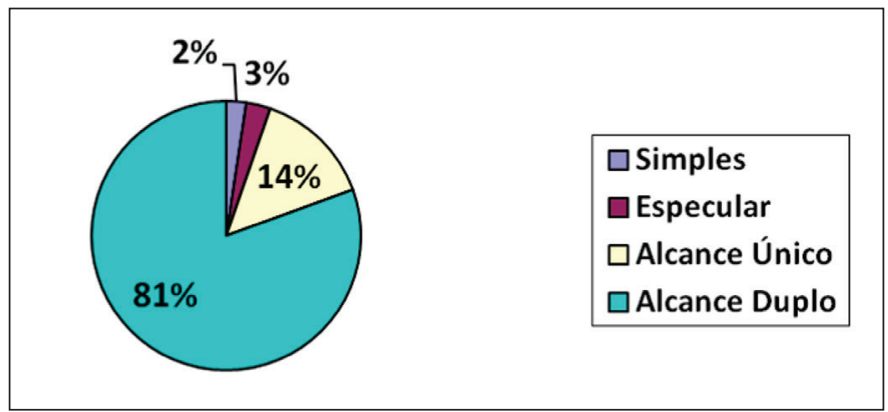

Fonte: Dados da pesquisa.

Como se pode observar, a grande maioria das ocorrências foi classificada como rede de alcance duplo. Isso se deu devido à grande recorrência do fenômeno de mesclagem de vozes no corpus VALPB. Percebemos que, na maioria das vezes, quando esse evento ocorre temos dois enquadres diferentes, sendo um o enquadre real da entrevista no espaço base e o outro o enquadre da situação do discurso reportado. Não é apenas o enquadre do discurso transposto que se projeta na organização da mescla, pois o falante continua sendo o "senhor da voz" (CHIAVEGATTO, 1999). Ele não copia o discurso que está recontando, mas ele o embute no seu próprio discurso moldando-o segundo seu ponto de vista atual. Isso ocorre tanto quando o informante retoma a voz de outra pessoa, quanto nos momentos em que ele reporta a sua própria voz em uma situação específica, geralmente, do passado. Assim, temos dois enquadres diferentes, ambos se projetando na organização da mescla, o que, segundo a teoria, corresponde à estrutura de uma rede de alcance duplo.

Existem também casos em que o discurso reportado não apresenta dois enquadres diferentes. São exemplos em que o falante especula respostas e pensamentos de outras pessoas ou por vezes suas próprias respostas e pensamentos em situações específicas, mas sem sair do enquadre comunicativo da narração. Nesses casos, temos o informante A e ao mesmo tempo o informante A' se vestindo da voz do outro sem perder a sua identidade, em uma situação específica contada no discurso, ambos no enquadre da entrevista. Nesses casos, classificamos as redes como especulares, pois de acordo com a teoria das redes de integração conceptual, as redes especulares têm espaços mentais diferentes organizados pelo mesmo enquadre comunicativo que se projeta na mescla, resultando exatamente nessa ideia de "espelho" do qual o próprio nome se origina. A e A' representam a mesma pessoa em situações diferentes no mesmo enquadre comunicativo. 
Outro ponto observado durante esse processo de classificação diz respeito à existência de uma estrutura emergente. Até o presente momento, não encontramos exemplos nos quais a formação das redes não resultasse no espaço-mescla e na estrutura emergente. Inclusive na literatura estudada todos os exemplos apresentados sempre terminam na formação do espaço-mescla com sua estrutura emergente. Diante disso, pudemos constatar, até então, a validade da teoria nos exemplos analisados no corpus VALPB.

Apresentaremos, a título de exemplificação, um trecho da tabela correspondente ao informante feminino 1 já atualizada com a informação da tipologia das redes:

Tabela 2 - Tipologia de Redes do Informante Feminino 1

\begin{tabular}{|c|c|c|c|c|}
\hline OCORRÊNCIA & TIPOLOGIA* & INFORMANTE & LOCALIZAÇÃO & FRAGMENTO \\
\hline 1 & Alcance único & 1 & L 22-23 & $\begin{array}{c}\text {... houve uma } \\
\text { morte ali vizinha } \\
\text { perto de casa. }\end{array}$ \\
\hline OCORRÊNCIA & TIPOLOGIA* & INFORMANTE & LOCALIZAÇÃO & FRAGMENTO \\
\hline 2 & Simples & 1 & L 45-47 & $\begin{array}{c}\text {... o marido que eu } \\
\text { gostava era o pai } \\
\text { do meu filho }\end{array}$ \\
\hline OCORRÊNCIA & TIPOLOGIA* & INFORMANTE & LOCALIZAÇÃO & FRAGMENTO \\
\hline 3 & Alcance duplo & 1 & L 82 & $\begin{array}{l}\text { Eu digo:- "Olhe } \\
\text { filho, sua avó }\end{array}$ \\
\hline OCORRÊNCIA & TIPOLOGIA* & INFORMANTE & LOCALIZAÇÃO & FRAGMENTO \\
\hline 4 & Alcance duplo & 1 & L 82 & $\begin{array}{l}\text { Ela fay0: - "Oue } \\
\text { sua avó? }\end{array}$ \\
\hline OCORRÊNCIA & TIPOLOGIA* & INFORMANTE & LOCALIZAÇÃO & FRAGMENTO \\
\hline 5 & Alcance duplo & 1 & L 82-83 & $\begin{array}{l}\text { Eu digo: É avó } \\
\text { dele (...)tava na } \\
\text { casa da minha } \\
\text { mãe. }\end{array}$ \\
\hline OCORRÊNCIA & TIPOLOGIA* & INFORMANTE & LOCALIZAÇÃO & FRAGMENTO \\
\hline 6 & Especular & 1 & L 156 & $\begin{array}{l}\text { Ele num bebe pra } \\
\text { dize0 assim: - "Eu } \\
\text { vou janta0, vou } \\
\text { almoça0 e vou } \\
\text { dormi0, não. }\end{array}$ \\
\hline
\end{tabular}


OCORRÊNCIA TIPOLOGIA* INFORMANTE LOCALIZAÇÃO FRAGMENTO

Eu digo:(...) você

7 Alcance duplo $\quad 1 \quad$ L 168-169 i0 p0a cima dos outro0

\begin{tabular}{|c|c|c|c|c|}
\hline OCORRÊNCIA & TIPOLOGIA* & INFORMANTE & LOCALIZAÇÃO & FRAGMENTO \\
\hline 8 & Alcance duplo & 1 & L 175 & $\begin{array}{c}\text {... aí ele fica } \\
\text { reclaman0 (...) é p' } \\
\text { eu da0 }\end{array}$ \\
\hline OCORRÊNCIA & TIPOLOGIA* & INFORMANTE & LOCALIZAÇÃO & FRAGMENTO \\
\hline 9 & Alcance duplo & 1 & L 175-177 & $\begin{array}{l}\text { Eu digo: (...)Ela } \\
\text { pode pega0. }\end{array}$ \\
\hline OCORRÊNCIA & TIPOLOGIA* & INFORMANTE & LOCALIZAÇÃO & FRAGMENTO \\
\hline 10 & Alcance duplo & 1 & L 177 - 178 & $\begin{array}{c}\text { Ele fica: (...) a tua } \\
\text { cara na frente } \\
\text { dela! }\end{array}$ \\
\hline OCORRÊNCIA & TIPOLOGIA* & INFORMANTE & LOCALIZAÇÃO & FRAGMENTO \\
\hline 11 & Alcance duplo & 1 & L 193 & $\begin{array}{l}\text { aí ele: 'deixe da } \\
\text { tua (...) mentira' }\end{array}$ \\
\hline OCORRÊNCIA & TIPOLOGIA* & INFORMANTE & LOCALIZAÇÃO & FRAGMENTO \\
\hline 12 & Alcance duplo & 1 & L 194 & $\begin{array}{l}\text { Eu digo: - "Eu tô } \\
\text { (...) é verdade." }\end{array}$ \\
\hline OCORRÊNCIA & TIPOLOGIA* & INFORMANTE & LOCALIZAÇÃO & FRAGMENTO \\
\hline 13 & Alcance duplo & 1 & L 195 - 196 & $\begin{array}{l}\text { aí ele disse que } \\
\text { era mentira }\end{array}$ \\
\hline OCORRÊNCIA & TIPOLOGIA* & INFORMANTE & LOCALIZAÇÃO & FRAGMENTO \\
\hline 14 & Alcance duplo & 1 & L 196 & $\begin{array}{l}\text { Eu digo: (...) pra } \\
\text { você ve0. }\end{array}$ \\
\hline
\end{tabular}

Fonte: VALPB. 
A partir daqui, iniciamos o processo de análise das ocorrências, organizando as análises por informantes e separando os informantes femininos dos masculinos. Apresentaremos abaixo análises realizadas de acordo com cada tipo de rede:

\section{Quadro 1 - Exemplo: Informante 1}

\section{Rede Simples}

\section{Informante 01}

Informante: $M H S$

Faixa etária (Anos): 15 a 25

Anos de escolarização: nenhum

Sexo: feminino

Linhas: 736-738

$E^{*}$ Se você fosse presidente o que você faria pelo Brasil?

$I^{\star}$ Ajuda0 os pob0e0, faze0 casa p0os pob0e0. Ajuda0, assim, da0 feira:, tudo que eles precisasse eu dava.

Fonte: VALPB.

Espaço influente 1: Espaço de base, estão presentes a pessoa do atual presidente do Brasil na época da entrevista e o informante 1.

Espaço influente 2: Espaço hipotético, possui um elemento que corresponde a um presidente do Brasil hipotético.

Espaço genérico: O espaço genérico compartilha a característica abstrata ser homem, em que homem é usado de maneira generalizada designando os seres humanos em geral.

Os elementos do espaço de base se projetam para o elemento do espaço contrafactual e há uma relação de identidade entre eles. Em outras palavras, o elemento informante 1 se projeta para o elemento presidente do Brasil do espaço hipotético, estabelecendo uma relação de identidade entre esses dois itens. Do espaço 1 se projeta o elemento sem enquadre informante 1 e do espaço 2 se projeta a função presidente do Brasil, esses dois elementos se projetam no espaço-mescla no qual há uma fusão de identidades. A mescla incorpora o enquadre do espaço influente 2 que é organizado pela função que um presidente cumpre ao exercer o cargo. 
No espaço-mescla, surge uma estrutura emergente: o informante 1 passa a ser, em um espaço hipotético, o presidente do Brasil, assumindo sua função e autoridade. Desse modo, o informante pode dizer o que poderia fazer nessa função como se realmente estivesse assumindo o cargo. É importante ressaltar que os elementos dos espaços influentes se projetam parcialmente para a mescla e se fundem, não há, portanto, uma soma de elementos, o que ocorre é realmente uma mescla entre os elementos de um espaço e do outro. Veja, por exemplo, que elementos dos enquadres, como tempo (presente e futuro), sexo (da informante, do presidente) não se somam, mas são projetados seletivamente para a mescla a fim de elaborarem a estrutura emergente.

Podemos dizer que na mescla ocorre uma compressão de relações vitais de analogia e de identidade ao mesmo tempo entre os elementos informante 1 e presidente do Brasil. No que diz respeito à relação vital de analogia, é possível desmembrar essa rede em duas: a primeira tem, em um espaço (input 1), a função presidente do Brasil e, no outro (input 2), a pessoa que exercia a presidência na época do enunciado como valor que preenche a função do input 1; a segunda rede tem um espaço (input 1) idêntico ao da primeira rede e, no outro espaço (input 2), o presidente hipotético (o informante 1), logo se estabelece uma relação de analogia entre o presidente real e 0 presidente hipotético. Ao mesmo tempo, existe um elo de identidade entre a função de cada rede desmembrada. Podemos dizer, neste caso, que ocorre uma compressão de função-valor entre essas duas redes que compartilham a mesma função.

Figura 3 - Compressão de Função-Valor.

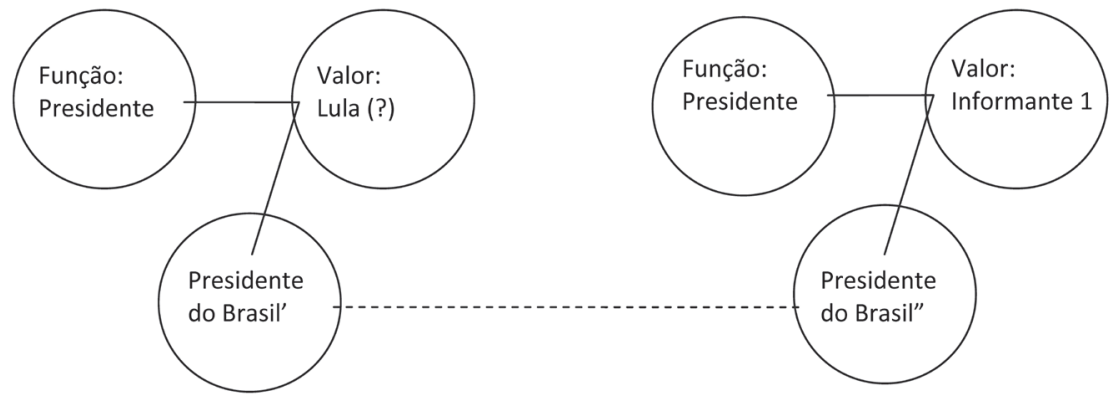

Fonte: Elaboração própria. 


\section{Informante 07}

Informante: $H B C$

Faixa etária (Anos): 15 a 25

Anos de escolarização: 9 a 11

Sexo: masculino

Linhas: 181-184

$E^{*}$ Como você escalaria essa seleção se fosse o técnico?

I* Primeøro, desde o inicio eu, essa seleção eu acho que os jogadores que têm de melhóø no Brasil foruø pra seleção. Agora eu [deixa] eu deixaria desde o início Romário. Eu num tiraria Romário, e nem levaria Taffarel.

Fonte: VALPB.

Espaço influente 1: É o espaço base, em que encontramos o informante 7, a pessoa do técnico verdadeiro e do time verdadeiro.

Espaço influente 2: É um espaço hipotético constituído por um técnico e uma seleção hipotéticos e possui enquadre organizado pelo contexto de equipe de time de futebol.

Espaço genérico: O espaço genérico compartilha a característica abstrata "ser homem", em que "homem" é usado de maneira generalizada, designando os seres humanos em geral.

Inicialmente o elemento informante 7 se projeta para o elemento técnico da seleção que está no espaço hipotético. O input do espaço hipotético com uma seleção e um técnico hipotéticos fornece um frame para organizar a rede de integração conceitual. Quando o intérprete constrói o input da realidade também constrói o input hipotético. A mescla contém informações sobre cada um dos espaços de input, bem como uma estrutura emergente que surge como produto do processo imaginativo de integração.

O espaço-mescla absorve o enquadre do espaço hipotético que contém um técnico hipotético que comanda uma seleção hipotética, e, nele, elementos do espaço de base cumprem papéis de suas contrapartes no espaço contrafactual, assim o informante 7cumpre papel de técnico da seleção. O evento contrafactual, no qual há a função de técnico, enquadra um relacionamento entre o informante 7 e a função de técnico da seleção. Ocorre, nesse caso, uma relação de compressão de identidade e analogia. Inicialmente observamos que na mescla há uma fusão 
entre o elemento informante 7 e a função técnico da seleção brasileira. Nessa fusão, identificamos a compressão de identidade entre esses elementos. Paralelamente, percebemos a compressão de analogia entre o técnico real e o técnico hipotético.

\title{
Quadro 3 - Exemplo: Informante 18
}

\author{
Informante 18 \\ Informante: $G G$ \\ Faixa etária (Anos): 26 a 49 \\ Anos de escolarização: 9 a 11 \\ Sexo: masculino \\ Linhas: 318-371 \\ (...) Eu se fosse de:: pelo menos assim:., o diretor de de uma emissora dessa, eu acho \\ que eu faria uma forma diferente, entende? Seria uma matéria mais:: curta e mais:: mais \\ sensata. \\ $E^{*}$ Mais objetiva. \\ $I^{*}$ Mais mais objetiva, mais sensata, entende? (...)
}

Fonte: VALPB.

Espaço influente 1: Encontramos o informante 18 e a pessoa real que dirige uma emissora. Esse é o espaço de base, da realidade.

Espaço influente 2: É um espaço contrafactual ou hipotético constituído por um diretor de emissora de tv hipotético. Este elemento é enquadrado pela função que um diretor de televisão possui no exercício do cargo.

Espaço genérico: O espaço genérico compartilha a característica abstrata ser homem, em que homem é usado de maneira generalizada, designando os seres humanos em geral.

O elemento informante 18 do espaço influente 1 se projeta para o elemento diretor de emissora de tv do espaço influente 2 e há uma relação de identidade entre eles. $O$ enquadre do espaço influente 2 se projeta para organizar a mescla. Na mescla, o elemento informante 18 e o elemento diretor de emissora de tv se projetam para a mescla. Na mescla, o item informante 18 assume a função da sua contraparte no elemento diretor de emissora de tv do espaço influente 2. Ocorre na mescla uma compressão de identidade entre o elemento projetado do espaço influente 1 e o elemento projetado do espaço influente 2. Ao mesmo tempo 
ocorre uma compressão de analogia na mescla conceitual. Podemos desdobrar a rede em duas envolvendo a função diretor de emissora de tv, em uma rede essa função se projeta no diretor de tv encontrado no espaço de realidade, na outra rede temos essa mesma função projetada ao informante 18, que é um diretor hipotético. Nesse caso, ocorre uma compressão de analogia entre o diretor real e o diretor hipotético que é a pessoa do informante 18.

\title{
Quadro 4 - Exemplo: Informante 7
}

\section{Rede de Alcance Único}

\author{
Informante 07 \\ Informante: $A H S-1 S F$ \\ Faixa etária (Anos): 15 a 25 \\ Anos de escolarização: 9 a 11 \\ Sexo: feminino
}

Linhas: 124-128

$E^{*}$ Não? Você tem medo de alguma coisa?

$I^{\star}$ Tenho, perde0 a minha mãe. (risos F)

$E^{*}$ Porque?(certo)

I* Porque ela é a única é a única que que é por nós, né? sem a pessoa sem se a gente perder mãe, não encontra out0a de jeito nenhum, (est) por isso que eu tenho muito medo de perder ela.

Fonte: VALPB.

Espaço influente 1: Espaço relacionado a objetos concretos que podemos literalmente perder.

Espaço influente 2: Espaço abstrato relacionado ao conceito que temos de morte. Espaço genérico: Ambos os espaços compartilham a noção genérica deixar de ter (algo/alguém).

O informante 7se refere à morte continuamente em termos de perda. A rede de integração conceitual que se forma possui a seguinte estrutura: temos um espaço relacionado aos itens que podemos literalmente perder e outro espaço que contém a ideia que temos de morte e elementos relacionados a ela. Identificamos um espaço genérico onde os dois espaços de entrada compartilham a noção de 'deixar de ter (algo)' e uma mescla em que a morte de uma pessoa significa 
perder essa pessoa assim como perdemos objetos. Podemos dizer, nesse caso, que estamos conceitualizando morte como perda.

A noção relacionada a elementos concretos que podemos perder se projeta para o espaço que comporta a noção de morrer e ocorre uma relação de analogia entre morte e os elementos do input de perda. Percebemos que há dois enquadres diferentes estruturando os espaços influentes, um enquadre que organiza os elementos concretos e um enquadre que organiza os elementos abstratos. O enquadre relacionado aos elementos abstratos se projeta para organizar a mescla. Na mescla, há uma fusão entre o conceito que temos de morte e o conceito de perder objetos, de modo que a morte pode ser entendida e expressada em termos de perda, fazendo surgir, assim, uma estrutura emergente em que MORTE É PERDA.

\section{Quadro 5 - Exemplo: Informante 1}

\section{Informante 11}

Informante: IMS

Faixa etária (Anos): 26 a 49

Anos de escolarização: nenhum

Sexo: feminino

Linhas: 268-270

$E^{*} \mathrm{O}$ que você mais gosta no seu esposo?

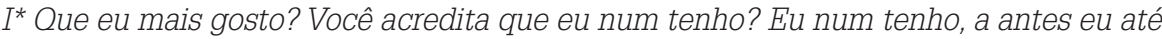
eu tinha, o que eu gostava antes, quando ele me dava um pouco de carinho, né? Um pouco só, e hoje em dia nem isso ele me dá mais (...).

Fonte: VALPB.

Espaço influente 1: Espaço relacionado a objetos concretos que podemos dar.

Espaço influente 2: Espaço relacionado ao conceito que temos de amor/carinho.

Espaço genérico: Ambos os espaços compartilham a noção genérica que algo que pode ser compartilhado.

O informante 11 fala de amor utilizando a noção de dar algo a alguém originando uma rede de integração conceitual de alcance único. Essa rede de integração conceitual contém um input envolvendo objetos concretos que é ativado pelo verbo dar e outro input envolvendo conceitos abstratos relacionado às noções amor e carinho. Existe um espaço genérico no qual objetos/conceitos 
podem ser compartilhados e um espaço-mescla que integra algumas estruturas de cada espaço de entrada.

Nesse exemplo, o input ligado a conceitos abstratos fornece o frame para organizar a mescla, e o frame do espaço que contém objetos concretos não é projetado a não ser para explicar a metáfora que se realiza na construção linguística dos dois informantes. O domínio que contém elementos concretos se projeta no domínio com elementos abstratos e há uma relação de analogia entre eles.

Na mescla se projeta uma representação parcial dos elementos concretos e das noções abstratas de amor, de modo que, na estrutura emergente, amor cumpre papel de objeto que pode ser 'dado' a uma pessoa assim como 'damos' qualquer outro objeto concreto, como um lápis, uma bola, um livro, etc. É importante perceber que na mescla há uma fusão entre os elementos parcialmente projetados, não é a soma da ideia de amor mais a de objeto, mas ocorre uma fusão de conceitos, em que amor se torna um objeto, gerando a metáfora conceitual AMOR É UM PRESENTE.

\section{Quadro 6 - Exemplo: Informante 5}

\section{Informante 05}

Informante: GSF

Faixa etária (Anos): 15 a 25

Anos de escolarização: 5 a 8

Sexo: feminino

Linhas: 216-225

E* Você já perdeu alguém muito querido Germana?

$I^{*}$ Já perdi meu primo.

$E^{*}$ Como foi?

$I^{*}$ Foi que ele tinha um pooblema, sofria de baço, e o médico proibiu que ele num pegasse em peso nenhum, e dali ele foi fazen0o extravagança, foi fazen0o extravagança, e ele perdia muito sangue, quando ele vinha pra cá p0a João Pessoa ele perdia sangue, o médico proibiu ele num pega0 muito em peso, e ele continuava pegan0o em peso; e dali quando ele vei a última veyz o médico disse que ele num ia escapar e isso me doeu muito, eu gostava muito dele, era o primo que eu mais gostava, e foi o tempo dele i0 embora, e aí eu chorei muito, mas eu num podia faze 0 nada, porque partida final é muito ruim .

Fonte: VALPB. 
Espaço influente 1: Espaço mais concreto relacionado à viagem.

Espaço influente 2: Espaço mais abstrato relacionado ao conceito que temos de morte.

Espaço genérico: Ambos os espaços compartilham a noção de ausência de alguém.

Os elementos do espaço de viagem se projetam para os elementos do espaço mais abstrato relacionado ao conceito de morte e estabelece-se uma relação de analogia entre eles. O espaço influente 1 possui elementos relacionados à viagem e um enquadre de viagem; o espaço influente $2 \mathrm{com}$ conceitos que temos relacionados à morte tem um enquadre comunicativo que envolve o que entendemos sobre morte, que se projeta para organizar a mescla.

Na mescla, são projetados parcialmente os dois espaços influentes, ou seja, a noção de viagem em analogia com a de morte se projetam e se fundem no espaço-mescla. No espaço-mescla, encontramos uma estrutura emergente em que a morte é entendida como uma viagem sem volta e, assim, podemos falar de morte usando noções ligadas à viagem. Essa rede de integração conceitual forma uma metáfora conceitual na qual MORTE É VIAGEM.

\section{Quadro 7 - Exemplo: Informante 3.}

\section{Rede de Alcance Duplo}

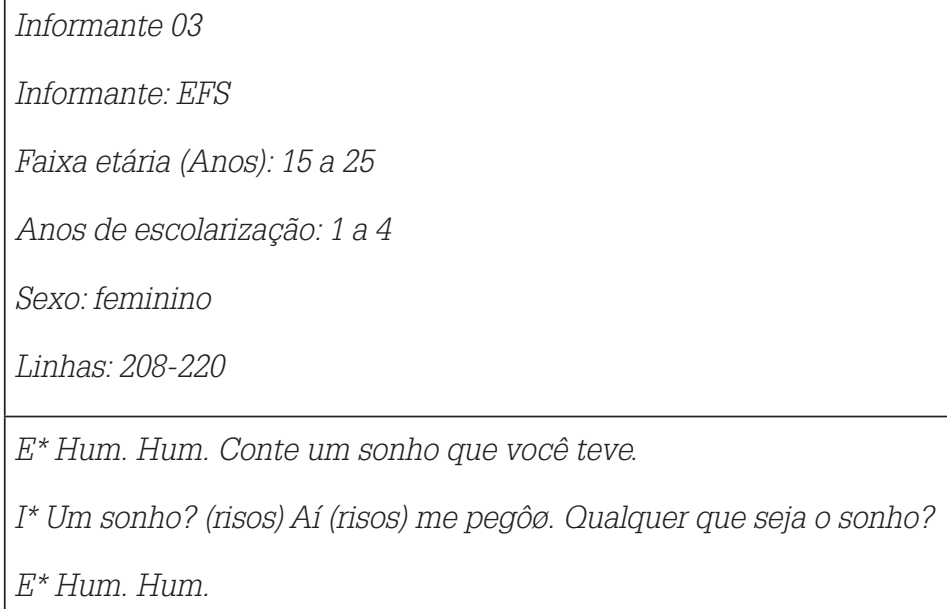




\begin{abstract}
$I^{\star}$ Eu já sonhei, deixa eu: eu tive um sonho que: eu tava: eu: de repente eu ficava grávida, né? Eu digo: "Ôxenti, eu grávida? Mais eu: eu eu fui: ligada, como é que eu posso tá grávida?" Aí eu disse: "Se realmente eu tiver grávida, ah, o médico que feyz a minha cirurgia, menina, eu vou dar uma esculhambação nele" (risos) Aí: de repente: nasce o menino, menino macho, eu digo: "Êita!", lindo dos olho azul, branquinho, eu digo: "Aí que coisa linda. Meu Deus!" Então, eu disse: "Apois, depois: que eu: tiraø esse menino, eu vou: atráys do médico que feys a minha cirurgia e vou esculhambar, porque: isso né é coisa que se faça não. Fazeø a pessoa entrar numa sala de cirurgia, sem têø: nenhuma doença, boa de saúde, só pra fazeø isso, de repente, meu Deus, engravidaø novamente, é muita falta de (risos) de consideração pelo ser humano, o médico fazer uma coisa dessa. Esse foi o sonho que eu tive.
\end{abstract}

Fonte: VALPB.

Espaço influente 1: Espaço de base, realidade, enquadre que situa o contexto em que ocorre a narração. Neste está a informante 03.

Espaço influente 2: Espaço mental no qual se situa o sono, é organizado pelo enquadre do sonho que é narrado. Neste segundo espaço, encontramos a informante 03'.

Espaço genérico: Tanto o espaço influente 1 quanto o espaço influente 2 compartilham uma noção genérica, relacionada a acontecimentos da vida de uma pessoa.

Inicialmente, ocorre uma projeção entre o item informante 03 do espaço de base e do item informante 03' do espaço do sonho. Ambos se projetam na mescla e há uma relação de identidade entre eles. O enquadre do sonho e o enquadre em que ocorre a narrativa, no espaço da realidade, também se projetam na mescla e há uma fusão entre eles, podemos dizer que ocorre uma compressão de relação de espaço entre o espaço do sonho e o espaço da realidade. No espaço-mescla, temos uma estrutura emergente em que encontramos a informante 3 " numa fusão entre o espaço de base e o espaço do sonho, ao mesmo tempo, ao se reportar ao sonho em forma de narrativa. Percebemos uma mescla bastante criativa que emerge da fusão de dois enquadres diferentes, daí a classificação como rede de alcance duplo. 


\section{Informante 30}

Informante: WL

Faixa etária (Anos): mais de 50

Anos de escolarização: mais de 11

Sexo: masculino

Linhas: 296-311

$E^{*}$ Como foi sua juventude?

I* Minha juventude foi péssima, moça. Eu, como tava dizendo, né? Péssima da seguinte maneira, não é pela rigidez. Eu vou contar um fato aqui pra você, da seguinte maneira. eu fui fazer teste no Botafogo e passei. Eu passei. Teve dois treinos no Botafogo, que era ali ali em Jaguaribe, onde tem um posto Nossa Senhora da Penha, ali, naquele quarteirão todinho era um campo de futebol. E acontece que, eu quando cheguei, em casa de onze horas, minha mãe disse que eu não tornasse fazer mais aquilo, que ela não abria a porta mais não. E eu tinha dezoito anos, viu? Outra, eu quando trabalhava no Correio da Paraíba, eu tinha um um colega chamado Cleino Batista do Anjos, irmão dessa vereadora Creuza, que é dona ali do Pires, Bagunça, sei o que? Cleino Batista dos Anjos, foi pra o Rio e mandou uma carta pra um colega meu, Marajor, pra mim e Marajor, fazer um teste no América do Rio. Eu tinha dezenove anoø. Mãe disse: "Você não vai não! que você não tem tem ninguém lá não." Mas eu disse: Eu tenho minha profissão. Se não der certo futebol, eu vou enveredar pela minha pela pela minha profissão, que é lotipista. E mesmo assim, eu não tive respaldo, e [nem tinha] nem eu tinha coragem. Porque uma ordem naquela época duma duma mãe, um pedido, uma ordem era coisa séria \{inint\}. A gente levava a gente levava a coisa a sério mesmo. Mays hoje não, a gente vê a maior discordância <dos pais> dos filhos [co] para com os pais.

Fonte: VALPB.

Espaço influente 1: Espaço de base, da realidade, organizado pelo enquadre em que o indivíduo elabora a narrativa. Nele encontramos o informante 30.

Espaço influente 2: Espaço no qual se situa a história contada. É organizado pelo enquadre da conversa com a mãe (nos trechos em negrito) e possui como elementos: o informante 30', sua mãe, o time que o indivíduo jogava. 
Espaço genérico: Tanto o espaço influente 1 quanto o espaço influente 2 compartilham uma noção genérica relacionada a acontecimentos da vida de uma pessoa.

O elemento informante 30 se projeta para informante 30' e há uma relação de identidade entre eles. Esses elementos também se projetam para o espaçomescla. Ocorre também uma projeção do informante 30 para o elemento mãe, situado no espaço em que ocorre a história contada. O elemento mãe também se projeta para o espaço-mescla. Ocorre uma projeção do elemento mãe também para o espaço-mescla.

O enquadre do momento da narrativa e o enquadre da conversa com a mãe se projetam também para o espaço-mescla e há uma fusão entre eles. O informante 30 " que é a fusão do informante 30 no informante 30' reproduz ao mesmo tempo a voz do personagem informante 30'e do narrador informante 30, mesclando, nele mesmo, essas duas funções e vozes.

O informante $30^{\prime \prime}$ se situa no espaço-mescla e surge com a estrutura emergente. No espaço-mescla, também encontramos uma fusão entre o elemento mãe e o informante 30. Há uma compressão de analogia entre o entre o informante 30 do espaço de base e a pessoa da mãe que está presente no espaço da narração, pois ambos assumem função mãe no espaço-mescla.

Há também uma compressão de identidade em que o informante 30 passa a ser a mãe ao assumir a sua voz durante a narração o que se constitui em uma mesclagem de vozes. Temos, assim, no espaço-mescla: uma fusão entre o enquadre real em que indivíduo elabora a narrativa e o enquadre da situação de conversa com a mãe; uma fusão entre o informante 30 do espaço de base e o informante 30' do espaço que remete à situação do passado; e uma outra fusão entre o informante 30 e sua mãe, por meio da mesclagem de vozes entre o narrador e o personagem mãe.

No espaço-mescla, o informante 30 está ao mesmo tempo no presente e no passado (na história contada) e é ao mesmo tempo o narrador e os personagens informante 30' e mãe na narrativa. Chamamos atenção mais uma vez para a capacidade criativa das redes de alcance duplo que pode ser observada na complexidade dos mapeamentos e na estruturação da estrutura emergente. 


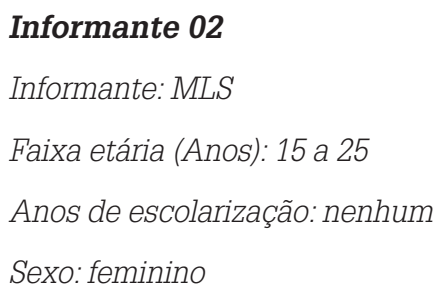
essa: a morte de meu pai. Eu tava na cozinha com a minha prima fazendo: uma comida, aí de repente, chegôø: parôø um carro na frente da minha casa, e eu não sabia quem era, aí vim atendeø. O rapays bateu na porta, eu vim atender, aí eu disse: "Diga." Aí ele falou: "É aqui que mora José Fernandes?". Eu disse: "Não é aqui mais é meu pai". "Porque: ele acabou de faleceø". Aí eu disse: "Num acredito". Ele disse: "Foi". Eu disse: "De que horas?". Aí, ele feys: "Foi de: uma hora". Eu disse "Uma hora da tarde e agora quatro hora da tarde, você vem daø essa notícia?". Ele feyz: "É porque eu tava: danøo outras notícia fora fui pra Jacaraú, levaø um: um morto, e cheguei agora". Ele disse: "Só agora pude vir dá a notícia". Eu disse: "Mais é muita irresponsabilidade de vocês <vim> uma pessoa morrer de uma hora: uma hora da tarde e vem daø a notícia de quatro horas". Aí, ele feys: “O que é que se á de fazeø?". Eu acho que essa foi a notícia mais triste que eu recebi.

Fonte:VALPB.

Espaço influente 1: Espaço da realidade em que a narradora conta a história. Nesse espaço, temos a informante 02 e o enquadre organizacional da situação em que ela elabora a narração.

Espaço influente 2: Espaço que remete ao passado em que se passa a história que é contada pela narradora. Nele encontramos a informante 02', os rapazes que vêm dar a notícia da morte, o pai que morreu e a prima que estava com ela. $\mathrm{O}$ enquadre em que se organiza esse espaço é o enquadre em que ocorre a discussão entre os rapazes e a informante 02 .

Espaço genérico: Tanto o espaço influente 1 quanto o espaço influente 2 compartilham uma noção genérica relacionada a acontecimentos da vida de uma pessoa.

Há uma projeção entre a informante 02 do espaço de base e a informante 02' do espaço que remete ao passado. Há também uma projeção entre a informante 02 
e os rapazes do espaço em que ocorre a narrativa. O informante $02 \mathrm{e}$ o informante 02' se projetam para a mescla, bem como os rapazes do espaço influente 2 . Os enquadres comunicativos de ambos os espaços influentes se projetam para a mescla conceitual.

Na mescla ocorre uma fusão entre a informante 02 e a informante 02', há uma compressão de identidade entre esses dois elementos. Também acontece uma compressão de identidade entre a informante 02 e os rapazes do espaço influente 2. Há uma mesclagem de vozes entre a voz da narradora que é a informante 02 e a voz da personagem informante 02', há também uma mesclagem de vozes entre a informante 02 e a voz dos rapazes que dialogam com a informante 02' na narrativa.

Ocorre uma fusão dos enquadres dos dois espaços influentes e, na estrutura emergente, temos ao mesmo tempo narradora e personagens falando através da mesma voz. Ocorre também uma compressão de tempo e de espaço e se observa, na estrutura emergente, a narradora/personagem que se situa no passado e no futuro ao mesmo tempo, em seus respectivos espaços, bem como nos enquadres comunicativos dos dois espaços influentes. Mais uma vez chamamos atenção para que o que ocorre na estrutura emergente não é a soma desses elementos, mas a integração de todos eles.

\section{Quadro 10 - Exemplo: Informante 11}

\section{Redes Especulares}

Informante 11
Informante: IMS
Faixa etária (Anos): 26 a 49
Anos de escolarização: nenhum
Sexo: feminino
Linhas $448-454$
E*O que você pensa sobre a violência no mundo de hoje?
I*O que eu penso? + Olhe, eu penso muito nisso aí, sabe? Penso muito. + E eu penso
que: se Deus num tiver compaixão de nóys, a gente num vai esperar uma melhora não,
daqui a pior. Eu penso assim Deus:, como Deus é bom, né? mays, + é como diz o ditado,
né? daqui pra frente, nóys sóys vê, vamu só veø o pior, né? Fim de geração, né? Eu num
$<$ te-> eu num confio mais em ninguém, eu num confio mais em nada na minha vida.
Às veyzø eu penso assim, eu penso assim, olhe: “Uma mãe, um filho, um pai,
mata <ass-> mata o o: um filho mata o pai, o filho mata uma mãe”.

Fonte: VALPB. 
Espaço influente 1: Espaço mental de base em que há o informante 11 e sua realidade. O enquadre organizacional é o enquadre em que ocorre a entrevista, a situação em que o informante relata os acontecimentos.

Espaço influente 2: Espaço em que ocorre o pensamento da informante 11. Nele está presente o próprio informante 11. É organizado por um enquadre relacionado ao pensamento e às conjecturas que fazemos.

Espaço genérico: Tanto o espaço influente 1 quanto o espaço influente 2 compartilham uma noção genérica relacionada a acontecimentos da vida de uma pessoa.

O informante 11 do espaço influente 1 se projeta para o informante 11 do espaço influente 2. Ambos se projetam para o espaço-mescla. O mesmo enquadre se organiza nos espaços influentes e se projeta na organização da mescla que é o enquadre da situação em que o informante se encontra no espaço da realidade. No espaço-mescla, há a fusão entre o informante 1 do espaço da realidade e o informante 2 do espaço da imaginação. Na mescla, há a fusão entre os informantes 11 dos dois espaços influentes e ele, duplamente, é o ser que imagina e que conta o pensamento dentro do mesmo enquadre comunicativo proveniente dos espaços mescla na estrutura emergente.

\section{Quadro 11 - Exemplo: Informante 18}

\section{Informante 18}

Informante: $G G$

Faixa etária (Anos): 26 a 49

Anos de escolarização: 9 a 11

Sexo: masculino

Linhas 580-588

I* Ah! O carnaval desapareceu, né? Não existe mais carnaval, pelo menos, ao tempo de de meu meu no tempo que eu conheci o carnaval, eu conheci o carnaval, né? Meus antecessores já conheceram melhor:.: certo? <Éntão, o carnaval é um passeio assim>. A liberdade essa integrada, né?

$E^{*}$ Agora tá muito... 
$I^{*}$ Não, desapareceu é porque (hes.) realmente:: você não tem segurança em sair de casa hoje Pra dizer: "Vou brincar o carnaval", você tem medo, exatamente.:, o mascarado é realmente se aproveitam disso aí \{inint.\} pra fazer uma:: uma tragédia, né? E a pessoa que quer segurança, apenas teme e não sai::, prefere ir às praias, que você vê hoje que exatamente o carnaval:: rola mais na praias, entende?

Fonte: VALPB.

Espaço influente 1: Espaço de realidade em que existe o informante 18, situado sob o enquadre da situação real em que se encontra na entrevista.

Espaço influente 2: O espaço em que se situa o pensamento, a imaginação, o próprio informante 18 e o mesmo enquadre comunicativo da realidade.

Espaço genérico: Tanto o espaço influente 1 quanto o espaço influente 2 compartilham uma noção genérica relacionada a acontecimentos da vida de uma pessoa.

O informante 18 do espaço influente 1 se projeta para o informante 18 do espaço influente 2 . Ambos se identificam e se projetam para a mescla. O enquadre que organiza os dois espaços influentes é o mesmo e se projeta também para a mescla conceitual. Na mescla, temos a mescla entre o informante 18 dos espaços influentes 1 e 2, o enquadre organizacional do mesmo espaço e, em uma estrutura emergente, o informante 18 ao mesmo tempo falando em sua imaginação e na entrevista.

\section{Quadro 12 - Exemplo: Informante 12}

\section{Informante 12 \\ Informante: SMPS \\ Faixa etária (Anos): 26 a 49 \\ Anos de escolarização: nenhum \\ Sexo: feminino \\ Linhas: 169-178}

$E^{*}$ Você já esteve alguma vez em uma situação difícil, em que tenha dito a você mesma chegou a minha hora? 
I* Tive, + tive porque: eu tive: + eu tive muita dificuldade na minha vida já:, sofri demais já, + eu queria às vezeø eu ficava assim pensanøo: "Meu Deuø, + eu queria arrumar um homem pra vim morar comigo, porque eu sofro demais. + Porque eu num tinha o que eu queria, sei lá, sofria muito em casa, assim, sobre negócio de: meu pai era pobre não tinha condição de daø nada, e a gente sofria sofria muito nas casaø dos outroø. + E pedia muito pra: arrumar uma pessoa que desse certo comigo, pra mim + viver veø se eu tinha um pouco de payz. Tinha hora que eu dizia assim: Eu queria tinha hora tinha hora que eu dizia: Eu queria morreø, preferia morrer do que viver numa situação dessa. Mayø até que fim que consegui + realizar meu sonho.

Fonte: VALPB.

Espaço influente 1: Espaço de base, em que se encontra o informante 12 na sua realidade. O enquadre organizacional é o que situa o informante 12 na entrevista.

Espaço influente 2: Espaço da imaginação, do pensamento do informante 12. Nesse espaço, encontramos uma contraparte do informante 12 que diz respeito ao seu pensamento. Esse espaço é enquadrado pelo mesmo frame do espaço comunicativo da situação da realidade.

Espaço genérico: Tanto o espaço influente 1 quanto o espaço influente 2 compartilham uma noção genérica relacionada a acontecimentos da vida de uma pessoa.

O informante 12 do espaço da realidade se projeta para o informante 12 do espaço da imaginação e ambos se projetam para o espaço-mescla. O enquadre comunicativo que organiza os dois espaços influentes se projeta para a mescla conceitual e a organiza. Na mescla temos a voz dupla do informante 12 que naquele momento elabora uma mesclagem da sua própria voz ao reproduzir um pensamento em uma situação específica.

\section{Considerações finais}

Com a presente pesquisa, procuramos investigar o comportamento das redes de integração conceitual e, por isso, empreendemos um trabalho cuidadoso de análise do funcionamento e do mapeamento dessas redes e da observação das relações de compressão. Vimos que em narrativas de indivíduos letrados e iletrados não há diferenças quanto à estrutura do mapeamento que se realiza de acordo com cada tipo de rede. Esses mapeamentos são autônomos em relação à forma como são apresentados. Em outras palavras, independente de como os indivíduos letrados ou iletrados elaboram os enunciados linguísticos que servem de gatilho 
para a formação de redes os mapeamentos, estes irão se realizar obedecendo à estrutura das tipologias às quais se submetem. Não há diferença de acordo com a tipologia das redes entre o mapeamento cognitivo realizado por indivíduos letrados ou iletrados.

Outro ponto interessante é visto no processo de compressão de relações vitais. Percebemos nas redes de integração simples a duplicidade das compressões de identidade e analogia que originaram a estrutura emergente. Isso deve acontecer nessa tipologia pelo fato de existir sempre uma relação de função-valor entre os elementos dos espaços o que é diretamente ligado à compressão de analogia. Nos casos em que percebemos a compressão de espaço e tempo há sempre uma rede bastante complexa que é a de alcance duplo.

No corpus estudado, tínhamos em sua maioria redes de alcance duplo relacionadas a estruturas narrativas em que o falante se reportava ao passado e assumia vozes dos personagens de suas histórias. Nesse ponto, bem como na análise das redes especulares, vemos a importância do conhecimento sobre o processo de mesclagem de vozes, pois em ambos os casos é um processo recorrente e essencial para a análise das redes. Os informantes assumem duas vozes nas narrativas que originam redes de alcance duplo: a voz do narrador e a voz dos personagens. Nesse caso, podemos afirmar que, além da compressão de tempo e de espaço envolvida, há ainda as compressões de analogia e de identidade, o que torna essas redes extremamente complexas e criativas.

No caso das redes de alcance único, vemos a presença predominante das analogias em que elementos de um espaço são análogos aos de outro espaço, ou seja, assumem a mesma função desses elementos dos outros espaços. Nas redes especulares, identificamos uma relação de analogia entre os informantes presentes nos dois espaços influentes. Como ambos compartilham a função de narrador, ambos se relacionam por analogia.

Entendemos que, a partir do exame das ocorrências de redes, temos acesso a uma gama de mapeamentos cognitivos que se posicionam por trás da linguagem. Esses procedimentos extremamente complexos constituem o pano de fundo da linguagem e nos permitem compreender a forma como os falantes compreendem o mundo, segmentam, compartilham, estruturam e reportam a realidade que os cerca.

\section{Agradecimentos}

Agradecemos o apoio do CNPq - Conselho Nacional de Desenvolvimento Científico e Tecnológico pelo apoio financeiro concedido na forma de Auxílio à Pesquisa, Processo 478634/2010-2. 
LEITE, J. E. R.; TOSCANO, M. N.; MARTINS, A. de O. G. Conceptual integration networks within Sociolinguistic narratives. Alfa, São Paulo, v.57, n.1, p.99-131, 2013.

- ABSTRACT: This paper aims at depicting the emergence of conceptual integration networks (CIN) in speech data collected from speakers of the socio-dialect from João Pessoa, Paraíba, Brazil. One of its goals is to map some cognitive strategies used by individuals to conceptualize accounts of reality. The corpus used is part of VALPB (Variação Linguística do Estado da Paraíba, Paraíba State Linguistic Variation), which profiles speakers according to sex, age, and schooling years variables. After gathering sufficient data, the CIN occurrences were counted, classified and analyzed; compressions of vital conceptual relations were observed within CIN and described as such; and network typology derived from various kinds of conceptual blend was identified in speakers' narratives. Theoretically, all cognitive assumptions results from work on mental spaces and conceptual integration, as proposed by Fauconnier and Turner (2002). Analysis' results were grouped according to CIN occurrences related to the variables presented in the corpus.

- KEYWORDS: Blending. Conceptual integration networks. Mirror network. Simple network. Single scope network. Double scope network. Conceptualization.

\section{REFERÊNCIAS}

CHIAVEGATTO, V. C. Um olhar sobre o processo cognitivo de mesclagem de vozes. Veredas, Juiz de Fora, v.3, n.1, p.97-114, 1999. Disponível em:

<http://www.uff.br/revistaveredas/edicoes-anteriores/>. Acesso em: 13 fev. 2011.

COULSON, S.; OAKLEY, T. Blending Basics. Cognitive linguistics, Cambrigde, p.175-196, 2003.

FAUCONNIER, G. Mappings in thought and language. Cambridge: CUP, 1997. . Mental Spaces. Cambridge: CUP, 1994.

FAUCONNIER, G.; TURNER, M. The way we think. conceptual blending and the mind's hidden complexities. Chicago: Basic Books, 2002.

FERRARI, L. V. Postura epistêmica, ponto de vista e mesclagem em construções condicionais na interação conversacional. Veredas, Juiz de Fora, v.3, n.1, p.116-128, 1999. Disponível em: <http://www.ufjf.br/revistaveredas/edicoes-anteriores/>. Acesso de 13 fev. 2011.

HORA, D.; PEDROSA, J. L. R. (Org.). Projeto variação lingüística no estado da Paraíba. João Pessoa: Idéia, 2001. 5 v.

MIRANDA, N. S. Domínios conceptuais e projeções entre domínios: uma introdução ao Modelo dos Espaços Mentais. Veredas, Juiz de Fora, v.3, n.1, p.8195, 1999. Disponível em: <http://www.uff.br/revistaveredas/edicoes-anteriores>. Acesso em: 13 fev. 2011. 
RODRIGUES, J. E. Domínios cognitivos na conceptualização. In:

Conceptualização na linguagem: dos domínios cognitivos à mente social. João Pessoa: Ed. da UFPB, 2010. p.61-90.

Cognição e semântica: da representação formal à conceptualização. In: MACEDO, A. C. P. de; FELTES, H. P. de M.; FARIAS, E. M. P. (Org.). Cognição e linguística: explorando territórios, mapeando percursos. Caxias do Sul: EDUCS; Porto Alegre: EDIPUCRS, 2008. p.89-125.

TURNER, M. Frame Blending. In: FAVRETTI, R. R. (Ed.). Frames, corpora, and knowledge representation. Bologna: Bononia University Press, 2008. p.13-32. Disponível em: <http://papers.ssm.com/sol3/papers.cfm?abstract_id=1321302>. Acesso em: 13 fev. 2011.

Recebido em 30 de setembro de 2011

Aprovado em 24 de novembro de 2012; 
